\title{
COVID-19, Short-selling Ban and Energy Stock Prices
}

\author{
Ikhlaas Gurrib1, Qian Long Kweh', Davide Contu', Firuz Kamalov² (D) \\ ${ }^{1}$ Faculty of Management, Canadian University Dubai, United Arab Emirates, ${ }^{2}$ Faculty of Engineering, Canadian University Dubai, United Arab \\ Emirates \\ Keywords: short selling ban, energy stock prices, covid-19 \\ https://doi.org/10.46557/001c.18562
}

\section{Energy RESEARCH LETTERS}

Vol. 1, Issue 4, 2020

We examine the short-selling ban imposed by the National Commission for Companies and the Stock Exchange of Italy, the authority that regulates the Italian securities market, on three Italian energy stocks. We find that the effect of the short-selling ban was temporary.

\section{Introduction}

Over the last decade, various demand and supply factors contributed to determining energy prices globally, including block chain technologies, depletion of natural resources, decoupling of economic growth from energy consumption, and weather conditions (Kyritsis \& Serletis, 2019). More recently, energy prices have been affected by COVID-19 (see Devpura \& Narayan, 2020). Acute shocks in oil prices were observed, increasing investors' appetite for non-equity assets (World Bank, 2020). Furthermore, the pandemic has caused a short-run liquidity and volatility shock, with one of the fastest historical declines in the stock market ever observed in Europe. In line with worsening economic and stock market indicators, a rise in short-selling was observed. This can amplify price falls in already distressed markets, potentially leading to systemic risks (European Commission, 2010). Hence, a few countries in Europe introduced a ban on short-selling (ESMA, 2020a).

In this work, we assess the impact of the constraint on short-selling focusing on the case of Italy-which is one of the most heavily impacted countries from COVID-19 (ECDC, 2020). ${ }^{1}$ The National Commission for Companies and the Stock Exchange of Italy (CONSOB) imposed the short-selling ban from March 18, 2020 to May 18, 2020 following positive opinion ${ }^{2}$ by ESMA (ESMA, 2020b), which had suggested an even longer ban (until June 18, 2020). By decomposing the impact of the ban in the pre-COVID-19, early COVID-19, as well as the pre- and post- short-selling ban stages, this work sheds light on whether the ban led to overpricing of stocks. We also investigate whether removing the ban after two months of implementation, as opposed to the initial three-month plan (recommended by ESMA), was justified. We assess whether the ban had a short-term or long-lasting impact on the risk and return of energy stocks.

\section{Literature review \\ 2.1 The impact of COVID-19 on energy stocks}

While previous research points towards potential links between macroeconomic variables and the energy sector (for instance, Drachal, 2016; Gurrib, 2018, 2019; Kang et al., 2017; Kilian, 2009), fewer studies have dealt more specifically with COVID-19 and its impact on energy markets globally. Fu \& Shen (2020) found a significant negative impact of COVID-19 on the performance of corporations in the energy industry, especially in heavily affected areas in China. Gil-Alana \& Monge (2020) found the oil market became inefficient when incorporating COVID-19 crisis data. Polemis \& Soursou (2020) examined the impact of the pandemic on Greek companies' returns, showing it affected returns of most firms negatively, yet with dissipating effect following the announcement of the national lockdown. Similarly, Albulescu (2020) assessed the impact of COVID-19 on oil prices and found only a marginal effect on crude oil after controlling for economic policy uncertainty and the U.S. market volatility. Bakas \& Triantafyllou (2020) studied the impact of the pandemic's uncertainty on the volatility of commodity markets, showing a significant negative effect on crude oil.

1 While there were only two cases at the end of January 2020, the coronavirus spread rapidly in Italy, reaching nearly 1.855 million as of December 15, 2020. The number of cases dropped in May, but increased further from August. A total of 65,000 deaths have been recorded to-date. As of December 2020, Italy has the highest number of confirmed deaths caused by the virus in Europe with the most affected group being the elderly.

2 As the European securities market regulator, ESMA, provides opinions based on their own risk assessments which build and complement risk assessments done by the National Competent Authorities (NCA), such as the CONSOB in Italy. The purpose of assessing risks in financial markets is to promote financial stability across European financial markets. Specifically, for the short-selling ban, ESMA assessed whether the measure was appropriate, proportional, and how long it would last. 


\subsection{Short-selling constraints}

Following Regulation (EU) No 236/2012, short-selling of shares may take place if sellers either borrowed the shares, have a binding agreement to borrow the shares, or have an arrangement with a third party (European Commission, 2012). A ban on short-selling is just one type of constraint which can be applied to short-selling activities. Additional constraints can be considered. Mitchell et al. (2001) suggested that short sellers could be required to post additional margins if the price of the shorted stocks rise. If they run out of equity, unmet margin calls can lead to closing positions at a loss. Furthermore, Almazan et al. (2004) found that there can be institutional constraints, as only about $30 \%$ of mutual funds can short-sell, and only $2 \%$ pursue short-selling. Non-centralized shorting can also cost in terms of the search time involved to find a lender. Consequently, ESMA ensures that in European regulated markets for short-selling to happen, an investor must have borrowed the instruments concerned, entered into an agreement to borrow these, or have an arrangement with a third party under which that third party has confirmed that the share has been located and has taken measures vis-à-vis third parties necessary for the investor to have reasonable expectation that settlement can be done when outstanding.

\section{Data}

In this work, we use the Italian stock market index (the FTSE MIB) Implied Volatility Index (IVI), which measures the 30-day annualized implied volatility of the underlying FTSE MIB Index employing option prices. Expected volatility is calculated from the prices of out of the money options available in the Italian Derivatives Market (IDEM), where the price of each option represents market expectations of future volatility. Oil volatility is based on the Chicago Board Options Exchange (CBOE) crude oil exchange traded fund (ETF) volatility index. Although this measure is based on the United States Oil Fund (USO), which mostly tracks daily price movements of the West Texas Intermediate (WTI) crude oil, it can be employed as a proxy to capture oil price fluctuations (Drachal, 2016; Naser, 2016). The cumulative number of COVID-19 cases in Italy is sourced from Statista. Daily data was obtained from January 1, 2019 to October 13, 2020 from FactSet and Borsa Italiana. We excluded from the analysis days linked to weekends and public holidays in Italy.

\section{Results \\ 4.1 Pre- and post- short-selling ban comparison}

Daily changes in the FTSE MIB and Italia Oil \& Gas indexes are shown in Figure 1. We compare data relative to one-week pre- and post- short-selling ban of $18^{\text {th }}$ March. We find that the FTSE MIB index fell by over $30 \%$ over the period $10^{\text {th }}-17^{\text {th }}$ March (pre-ban period), compared to a drop of $5 \%$ over the week $18^{\text {th }}-25^{\text {th }}$ March (post-ban peri- od). Over the same periods, the FTSE Italia Oil \& Gas index, which represents the performance of energy companies in Italy, fell by nearly $15 \%$ one week prior to the short-selling ban, but rose by $19 \%$ over the week post the ban implementation.

While volatility of returns for a financial product which mimics the performance of the broad FTSE MIB index is $1.59 \%(2.06 \%)$ in the pre (post) ban period ( $1^{\text {st }}$ January $2019-13^{\text {th }}$ October 2020), the return volatility for a financial instrument which mimics the performance of the Italian Oil \& Gas index is $1.78 \%$ (2.45\%) in the pre (post) period. The increased return volatilities leads to questioning whether the short-selling ban on the share prices did lead to the desired outcome.

\subsection{The impact of COVID-19 on stock prices of energy companies}

Figure 2 shows the effect of the COVID-19 pandemic during the early stages on the change in stock prices of the three energy companies, where the short-selling ban was imposed, including the effect of COVID-19 on the FTSE Italia Oil \& Gas index. They all share similar trends after February 19, 2020. This date is considered as the reference point for early COVID-19 impact, due to the increase in the number of cases reported in Italy.

In Figure 3, we report the change in the daily number of COVID-19 cases in Italy (per 100), the CBOE crude oil ETF volatility index, which captures the volatility in crude oil prices, and the average change in the daily volume of the three energy stocks (ENI, GSP, SRS) per 10,000. ${ }^{3}$

From February 19, 2020, there was an increase in the daily number of COVID-19 cases accompanied by a rise in both the crude oil volatility index and the 30-day annualized implied volatility of the MIB market index. The increase in COVID-19 cases started to taper off around March 19, 2020. During this time, there is also a decrease in the crude oil volatility, potentially explained by the fewer number of cases portrayed as an optimistic future view of the virus and its consequential impact on future economic activity.

Around that date, there was the introduction of the short-selling ban on restricted shares in Italy, where a significant fluctuation in volume prior to the selling ban is witnessed. The volume traded in a much more normalized manner following the ban. The ban was lifted two months later on May 19, 2020. Towards the end of April 2020, Italy witnessed the highest increase in crude oil price volatility. This was accompanied by a decline in the number of COVID-19 cases, a reduction in trading volume, and a decrease in the fluctuations of stock market index values. Except for days around April, oil price volatility, market index volatility and the change in the number of COVID-19 cases can be observed to follow an upward trend. The change in number of COVID-19 cases decoupled from the other two risk measures around September 19, 2020 when there was a gradual increase in the number of COVID-19 cases. The 


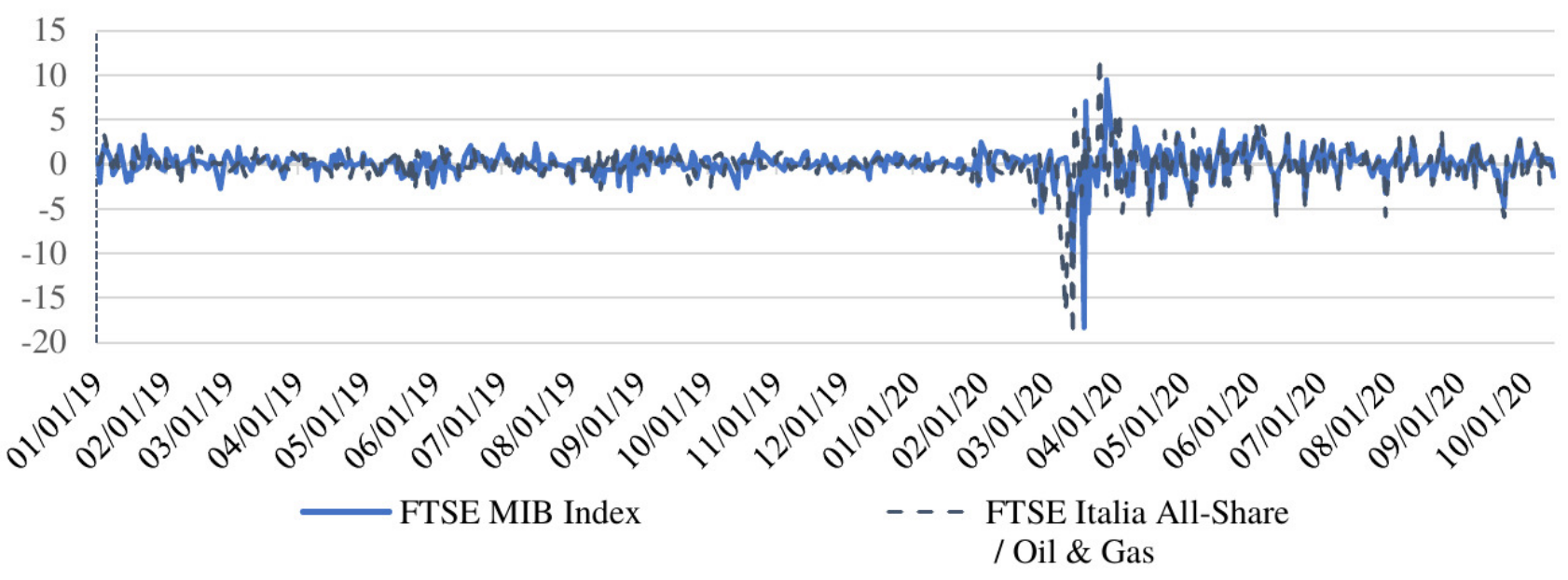

Figure 1. Daily change in FTSE MIB Index \& FTSE Italia Oil \& Gas Index

Note: This figure presents the calculated daily change in the Italian stock market index, viz. FTSE MIB Index (as represented by the blue line), and FTSE Italia Oil and Gas Index (as represented by the dashed, black line) from January 1, 2019 to October 13, 2020.

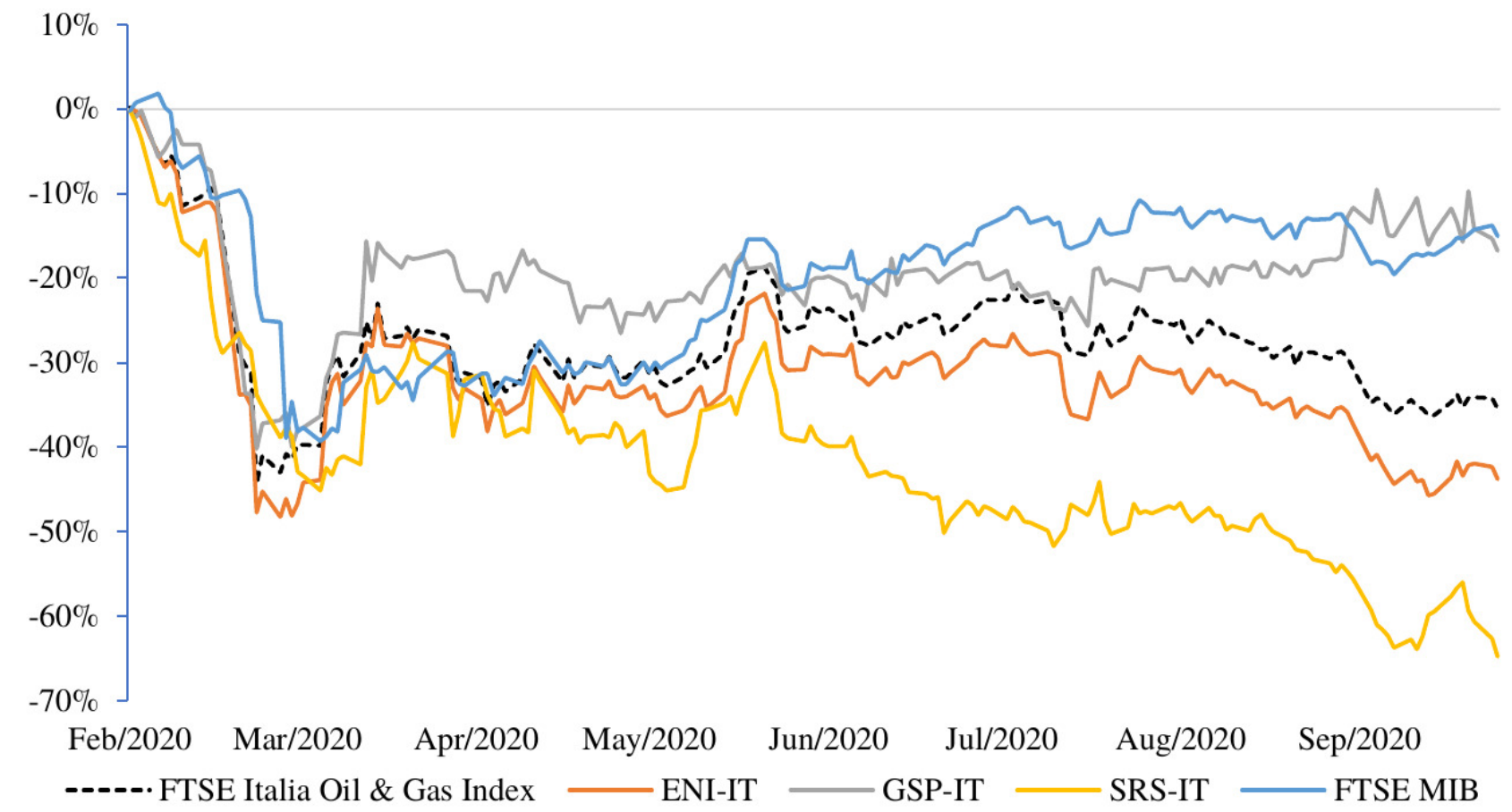

Figure 2. Market correction since early Covid-19

Note: This figure plots the market correction in the Italian stock market index, viz. FTSE MIB Index (as represented by the blue line), FTSE Italia Oil and Gas Index (as represented by the dashed, black line), three energy company (orange for ENI-IT, grey for GSP-IT, and yellow for SRS-IT) from February 2020 to October 2020 . Source: FactSet and Borsa Italiana.

change in volume witnessed a much more significant fluctuation than before the ban on short selling was imposed.

The average price of ENI-IT pre-ban was about USD15.62 (306 days) and dropped to approximately USD9.30 during the ban (41 days). Its average price rose to about USD9.32 in the post-ban period (106 days). By performing an ANOVA with the resulting $F$-test having a value of $1,023.51$, we found a significant difference in the stock prices of ENIIT before, during, and after the short-selling ban. The average prices of GSP-IT were about USD2.47, USD1.93, and USD2.03 in the pre-, during-, and post-ban periods, respec- tively. This price pattern which is also significantly different (with un-tabulated $F$-statistics $=354.09, p$-value $<0.01$, and degree of freedom $=450$ ) in the three different periods is similar to that of ENI-IT. That is, we observe a significant impact from the ban. However, in an impulse response test of stock price to FTSE Italia All-Share / Oil \& Gas, we also find that the prices corrected themselves, converging to the level observed during the ban for both ENI-IT and GSP-IT. These findings suggest that the impulse response from the short-selling ban could hardly last any longer. This is more evident in the average prices of SRS-IT, which dropped from 


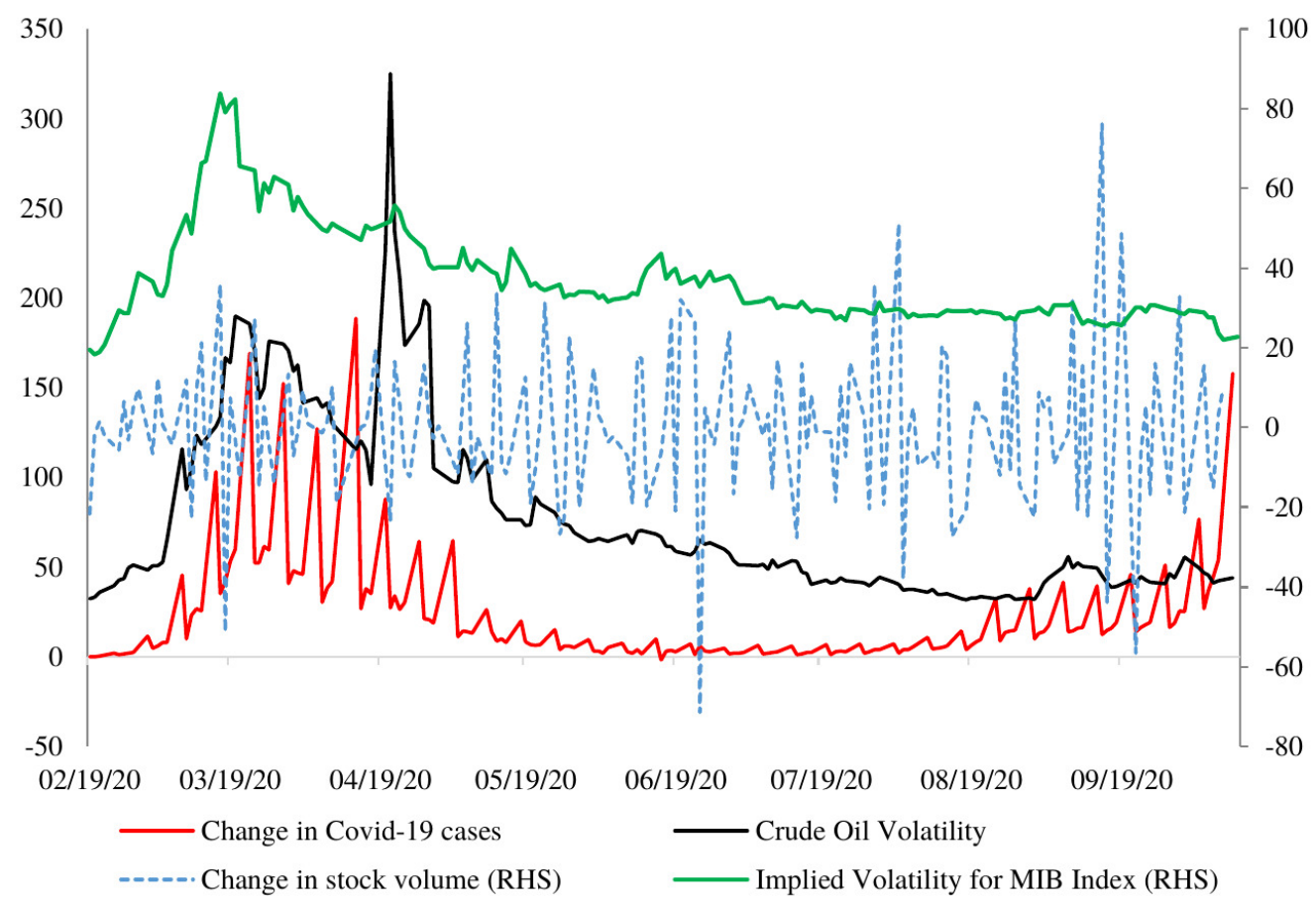

Figure 3. COVID-19 cases, volatility in oil \& market index \& FTSE Italia oil \& gas index

Note: This figure depicts the graph of COVID-19 cases in Italy (as represented by the red line), crude oil volatility (the black line, which is in the middle of the graph), changes in stock volume (the blue, dashed line), and implied volatility for MIB Index (the green line).

USD1.68 in the pre-ban period to USD0.88 in the ban period and then to USD0.73 in the post-ban period.

\section{Conclusion}

Soon after the COVID-19 outbreak in Italy, the Italian financial market witnessed a sharp decline in prices, coupled with increased market volatility. The situation deteriorated with the Italian major market index, the FTSE MIB, falling around 30\% over the period of March 10, 2020 March 17, 2020. While one can argue about the lack of liquidity in the market, the same period however saw an increase in volume: CONSOB reported an increase of nearly 23\% in net short positions between March 6, 2020 - March
12,2020 relative to the market capitalization value of the index, which rose from around $1.19 \%$ to $1.46 \%$. The shortselling ban helped mitigate the risk on energy stock prices when imposed, in line with ESMA which predicted that price falls will be contained. While the impact of the ban was significant, our findings reveal a short-lasting effect of this regulatory decision. This result provides financial market regulators, such as ESMA, some credible evidence as to why the short-selling ban was removed two months after its implementation. This also reaffirms the need for active monitoring by financial regulators, particularly during periods where market disruption is a real possibility. Future research can expand into analyzing the long-term effect of COVID-19 onto energy stock prices. 


\section{REFERENCES}

Albulescu, C. (2020). Coronavirus and Oil Price Crash. SSRN Working Paper. https://doi.org/10.2139/ssrn.35 $\underline{53452}$

Almazan, A., Brown, K. C., Carlson, M., \& Chapman, D. A. (2004). Why constrain your mutual fund manager? Journal of Financial Economics, 73(2), 289-321. https://doi.org/10.1016/j.jfineco.2003.05.00 7

Bakas, D., \& Triantafyllou, A. (2020). Commodity price volatility and the economic uncertainty of pandemics. Economics Letters, 193.

Devpura, N., \& Narayan, P. K. (2020). Hourly oil price volatility: The role of COVID-19. Energy Research Letters, 1(2), 13683.

Drachal, K. (2016). Forecasting spot oil price in a dynamic model averaging framework - Have the determinants changed over time? Energy Economics, 60, 35-46. https://doi.org/10.1016/j.eneco.2016.09.02 $\underline{0}$

ECDC. (2020). Covid-19 situation update for the EU/ EEA and the UK, as of November 9 2020. https://ww w.ecdc.europa.eu/en/cases-2019-ncov-eueea

ESMA. (2020a). ESMA Report on Trends, Risks and Vulnerabilities, No. 2, 2020.

ESMA. (2020b). Opinion of the European Securities and Markets Authority on: A proposed emergency measure by the Commissione Nazionale per le Società e la Borsa under Section 1 of Chapter $V$ of Regulation (EU) No 236/2012, ESMA70-155-9565, 17 March 2020.

European Commission. (2010). Proposal for a Regulation on Short Selling and Credit Default Swaps. MEMO/10/409. 15 September.

European Commission. (2012). Short selling: Technical Standards. MEMO/12/508. 29 June.

Fu, M., \& Shen, H. (2020). COVID-19 and Corporate Performance in the Energy Industry. Energy Research Letters, 1(1). https://doi.org/10.46557/001c.12967

Gil-Alana, L. A., \& Monge, M. (2020). Crude Oil Prices and COVID-19: Persistence of the Shock. Energy Research Letters, 1(1). https://doi.org/10.46557/001 c. 13200
Gurrib, I. (2018). Can an energy futures index predict US stock market index movements? International Journal of Energy Economics and Policy, 8(5), 230-240.

Gurrib, I. (2019). Can energy commodities affect energy blockchain-based cryptos? Studies in Economics and Finance, 36(3), 682-699. https://doi.o $\mathrm{rg} / 10.1108 /$ sef-10-2018-0313

Kang, W., Ratti, R. A., \& Vespignani, J. L. (2017). Oil price shocks and policy uncertainty: New evidence on the effects of US and non-US oil production. Energy Economics, 66, 536-546. https://doi.org/10.1016/i.en eco.2017.01.027

Kilian, L. (2009). Not all oil price shocks are alike: Disentangling demand and supply shocks in the crude oil market. American Economic Review, 99(3), 1053-1069. https://doi.org/10.1257/aer.99.3.1053

Kyritsis, E., \& Serletis, A. (2019). Oil Prices and the Renewable Energy Sector. Energy Journal, 40(01). htt ps://doi.org/10.5547/01956574.40.si1.ekyr

Mitchell, M. L., Pulvino, T. C., \& Stafford, E. (2001). Limited Arbitrage in Equity Markets. Harvard Business School Working Paper No. 01-069, HBS Finance Working Paper No. 01-069. https://doi.org/1 $\underline{0.2139 / \text { ssrn.267998 }}$

Naser, H. (2016). Estimating and forecasting the real prices of crude oil: A data rich model using a dynamic model averaging (DMA) approach. Energy Economics, 56, 75-87. https://doi.org/10.1016/j.eneco.2016.02.01 7

Polemis, M., \& Soursou, S. (2020). Assessing the Impact of the COVID-19 Pandemic on the Greek Energy Firms: An Event Study Analysis. Energy Research Letters, 1(3). https://doi.org/10.46557/001 c. 17238

World Bank. (2020). COVID-19 Outbreak: Capital Markets Implications and Response, Equitable Growth, Finance \& Institutions (Finance Series: Covid-19 Notes). World Bank Group. 